\title{
Effect of Biochar, Compost Tea and Magnetic Iron Ore Application on some Soil Properties and Productivity of Some Field Crops under Saline Soils Conditions at North Nile Delta
}

\author{
Megahed Mohamed Amer \\ Agriculture Research Center, Sakha Agricultural Research Station, Soil \\ Water and Environment Research Institute (SWERI), Giza, Egypt.
}

\begin{abstract}
TWO field experiments were conducted at Sakha Agric. Res. Station Farm, North Delta, during two seasons, summer of 2015 and winter of 2016 to study the effect of biochar, compost tea and magnetite iron ore application on some soil properties and its productivity under saline soil conditions. The experiments were designed as randomized complete blocks with three replicates. It is found that, salinity and sodicity of the soil were highly significant decreased due to different treatments after the harvesting of plants. Cation exchange capacity and soil porosity were highly significant increased due to individual application of biochar, compost tea, or magnetic iron ore and recorded the highest values by combination of treatments. While, bulk density was decreased soil infiltration rate and hydraulic conductivity were highly significant increased and recorded the highest value by combination of treatments after harvesting of plants. Soil nutrients availability, yield, water use efficiency and NPK uptake by crops were highly significant increased with individual treatments and recorded the highest values using combination of them. Total income, net income, economical efficiency and net income from water unit were highly significant increased by individual application of all treatments and recorded the highest values by combination of them. It could be concluded that $400 \mathrm{~L} \mathrm{fed}^{-1}$ of compost tea, $2.0 \mathrm{Mg}$ $\mathrm{fed}^{-1}$ as biochar amendments and $150 \mathrm{~kg} \mathrm{fed}^{-1}$ as magnetic iron ore application can be economically used for production of wheat and maize. The remediation of salt-affected soil in North Delta using previous soil amendments should be applied further, as an effective way of enhancing food crops productivity and improving some soil properties.
\end{abstract}

Keywords: Biochar, Compost tea, Magnetic iron ore, Net income, Saline soil, Soil properties, Wheat \& maize yield.

Wheat (Triticm aestivum L.) and maize (Zea mays L.) are considered the most two important cereal crops in Egypt. The amount needed is greater than that locally produced. Therefore, increasing its productivity as well as cultivated area is highly recommended. Many researchers showed that the organic matter content of the Egyptian soils is very low (between 0.5 and $2 \%$ ). It is well known that organic matter improves the clay soil structure, which increases water and nutrients retention capacity at the root zone, increases the microbial activity of the 
soil. Straw is a major output of the production of rice, wheat, cotton and maize (approximately two-third of the whole plant). Although there are several practices for the beneficial use of straw, i.e. compost, animal feed, roofing material, practical boards, bedding material, biochar and media for cultivation, actually it appears that a large volume of straw is wasted and burnt in the field by the farmers. To overcome this problem, the rice straw could be used as a source of compost and biochar. Moreover, most soils at North Delta are salt affected soils and suffering from the shortage of fresh water; consequently, affecting crops production.

Compost is comprised of a large and diverse community of microbes, humic acids and other chemical nutrients such as carbon and nitrogen that support soil and healthy plant growth. The good quality compost as an organic rich soil amendment can improve soil porosity, density improving nutrient uptake by the plant. Reviews of literature suggest compost tea may retain to varying degrees some of the same beneficial attributes of compost. Primary interest in application of compost tea versus compost is due to the fact that composts act more slowly over a long period of time and much larger amount is required. Part of the reason is that they encourage earthworms. Compost tea can be prepared in a shorter period of time and can be applied directly onto plant surface. However, effects of compost tea are short lived and frequent and repeat applications are required to replenish plant or soil surface with nutrient and/or beneficial microbes (Scheuerell \& Mahaffee, 2002 and Ingham, 2005).

Physical properties like bulk density, porosity and hydraulic conductivity were significantly improved when organic and chemical amendments were applied in combination resulting in enhanced wheat yield in sodic soil (Hussain et al., 2001). Several studies confirmed a significant positive effect of organic amendment to soils (Evanylo et al., 2008 and Carter et al., 2004). Getachew et al. (2015) concluded that the biochar and biochar-compost-based soil management approaches can improve cation exchange capacity, soil nutrient status and maize yield and may help mitigate greenhouse gas emissions in certain systems. Organic matter treatment in paddy fields could effectively alleviate the problem of soil salinity, resulting in yield improvement (Suriyan and Chalermpol, 2011).

Biochar application to soil influences various soil physico-chemical properties, due to its high specific surface area and because of direct nutrient additions via ash or organic fertilizer amendments as well as nutrient retention and availability being enhanced after biochar application (Glaser et al., 2002). Biochar could sorb salts and mitigate salt stress to plants through salt sorption, suggesting application of biochar to mitigate effects of salinity in agricultural soils (Thomas et al., 2013). Thus, ameliorating the salinity stress on maize and improving productivity in saline soils in arid and semiarid regions endangered increasingly by global climate changes. Biochar has a bulk density much lower than that of mineral soils $\left(\sim 0.3 \mathrm{Mg} \mathrm{m}^{-3}\right.$ for biochar compared to typical soil bulk density of $\left.1.3 \mathrm{Mg} \mathrm{m}^{-3}\right)$; therefore, the application of biochar can reduce the overall total bulk density of the soil, which is generally desirable for most plant growth (Brady and Weil, 2004). Biochar incorporation also

Egypt. J. Soil Sci. 56, No.1 (2016) 
could alter soil physical properties such as structure, pore size distribution and density, with implications for soil aeration, water holding capacity, plant growth and soil workability (Downie et al., 2009 and Schulz et al., 2013), thereby enhancement of soil fertility and crop yields (Brandstaka et al., 2010). Moreover, evidence suggests that biochar application into soil may increase the overall net soil surface area (Chan et al., 2007), consequently may improve soil water and nutrient retention (Downie $e t$ al., 2009). It is also stated that by growing maize in saline soil (EC $10.7 \mathrm{dS} \mathrm{m}^{-1}$ in soil paste), maize grain yield and stover yield were significantly increased due to organic and bio treatments (Poraas et al., 2008). Wheat yield also could be enhanced by biochar addition (Alburquerque et al., 2012). It is found also that, maize stoverbiochar increased maize biomass by $30 \%$ (Rajkovich et al., 2012). Amer et al. (2016) showed that organic application clearly improved the soil salinity, sodium adsorption ratio, exchangeable sodium percent and cation exchange capacity. Therefore, the application of organic amendments for soil remediation is important for sustainable land use and crop productivity (Wong et al., 2009).

There is not much research carried out on the effects of synergism and combination between compost tea, biochar and magnetic iron ore on both soils and plants. Thus, this research experiment was planned to evaluate the potential effect of compost tea, biochar and magnetic iron ore on changes in some soil properties as well as maize and wheat productivity under saline conditions at North Delta, Egypt.

\section{Materials and Methods}

\section{Experimental design}

Two Field experiments were conducted at Sakha Agric. Res. Station Farm, North Delta, during two successive seasons, summer of 2015 and winter of 2015/2016 to study the effect of biochar, compost tea and magnetic iron ore application on some soil proprieties and its productivity under saline soils. The experiments were designed as complete randomized blocks design with three replicates. The treatments were: control, biochar (B: $2.0 \mathrm{Mg} \mathrm{fed}^{-1}$ ), compost tea $\left(\mathrm{C}: 400 \mathrm{~L} \mathrm{fed}^{-1}\right)$, magnetic iron ore $\left(\mathrm{Fe}_{3} \mathrm{O}_{4} ; \mathrm{M}: 150 \mathrm{~kg} \mathrm{fed}^{-1}\right), \mathrm{B}+\mathrm{M}, \mathrm{C}+\mathrm{M}, \mathrm{B}+\mathrm{C}$ and $\mathrm{B}+\mathrm{C}+\mathrm{M}$. Biochar and magnetic iron ore were thoroughly mixed with the surface soil layer $(0-30 \mathrm{~cm})$ of the concerned plots. Before cultivation, both of wheat and maize plots received either biochar or magnetic iron enriched with micronutrients, where $400 \mathrm{~L} \mathrm{fed}^{-1}$ from compost tea blended with $1^{\text {st }}$ irrigation water and $2^{\text {nd }}$ irrigation as well as those received combination of them. Maize (single hybrid 10) was planted on $1^{\text {st }}$ May and harvested on $20^{\text {th }}$ September in the first season, 2015. Wheat (Sakha 94 variety) was planted on $15^{\text {th }}$ November 2015 and harvested on $25^{\text {th }}$ April in the second growing season of 2016. All cultural practices for the two crops were the same as recommended for the studied area. The experimental site was ploughed triple, settled, ridged and divided into plots (10 m length x $12 \mathrm{~m}$ width) during soil preparation. Seeds were obtained from Agriculture Research Centre, Giza, Egypt. Magnetic iron ore was obtained from Al-Ahram for Mining Company, Egypt. Compost tea preparation: $20 \mathrm{Kg}$ of maturing compost was taken and blended with tap water in dilution ratio 1: $10(\mathrm{w} / \mathrm{v}), 20$ kilogram of compost was put in plastic tanks and soaked into 200 liters of tap water. Then the mixture was turned daily and filtrated after 10 days, compost tea was enriched 
by Azospirillium spp.. The chemical composition of compost tea, biochar and magnetic iron ore can be listed in Table 1.

TABLE 1. Chemical composition of compost tea, biochar and magnetic iron ore.

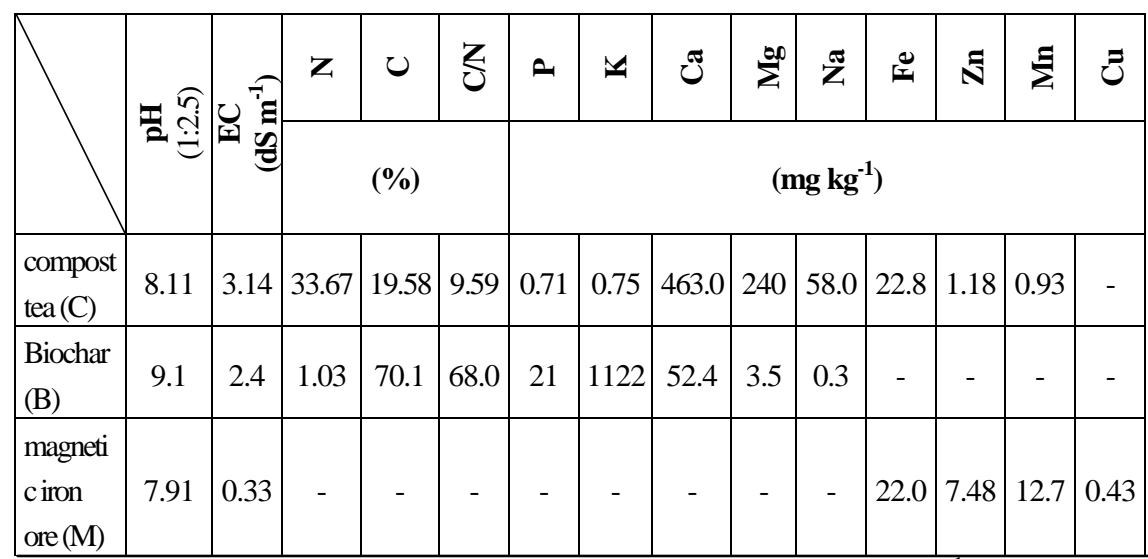

For magnetic iron ore: $\mathrm{pH}(1: 2.5)$ mineral: water suspension and $\mathrm{EC}\left(\mathrm{dS} \mathrm{m}^{-1}\right)$ in 1:5

\section{Soil sampling and analysis}

Soil samples were collected from the following depths 0-20, 20-40 and 40-60 cm in the initial and after harvesting of maize and wheat. The disturbed soil samples were prepared for physical and chemical analyses according to the standard methods. Exchangeable cations $\mathrm{Ca}, \mathrm{Mg}, \mathrm{K}$ and $\mathrm{Na}$, soluble cations and anions as well as soil $\mathrm{pH}$, EC, sodium adsorption ratio (SAR), organic matter and total calcium carbonate were determined according to Page et al. (1982). At the same time, undisturbed soil samples were taken to determine the bulk density according to Black and Hartge (1986), hydraulic conductivity was measured by auger hole method according to Van Beers (1958). Soil chemical and physical characteristics of the experimental site before cultivation were shown in Tables 2 and 3 .

TABLE 2. Soil chemical characteristics including sodium adsorption ratio (SAR), exchangeable sodium percent (ESP) cation exchange capacity (CEC) of the experimental site before cultivation (over mean two seasons).

\begin{tabular}{|c|c|c|c|c|c|c|c|}
\hline 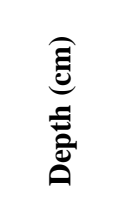 & 营 & 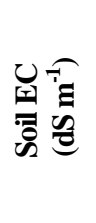 & 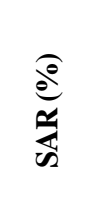 & 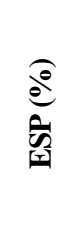 & U & 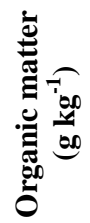 & 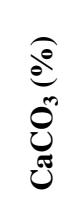 \\
\hline $0-20$ & 8.5 & 8.9 & 12.86 & 15.0 & 40.0 & 11.1 & 1.87 \\
\hline $20-40$ & 8.6 & 9.1 & 19.72 & 21.8 & 38.5 & 10.8 & 1.84 \\
\hline $40-60$ & 8.7 & 10.6 & 21.59 & 23.4 & 38.0 & 10.5 & 1.83 \\
\hline Mean & - & 9.5 & 18.1 & 20.1 & 38.8 & 10.8 & 1.85 \\
\hline
\end{tabular}

Soil pH in (1:2.5 soil: water suspension), whereas soil salinity (EC) in soil paste extract

Egypt. J. Soil Sci. 56, No.1 (2016) 
TABLE 3. Soil physical characteristics of the experimental site before cultivation (over mean two seasons).

\begin{tabular}{|c|c|c|c|c|c|c|c|c|c|c|}
\hline \multirow[b]{2}{*}{$\begin{array}{c}\text { Depth } \\
\text { (cm) }\end{array}$} & \multirow[b]{2}{*}{$\underset{\left(\mathbf{m ~ d}^{-\mathbf{1}}\right)}{\mathbf{K}}$} & \multirow[b]{2}{*}{$\begin{array}{c}\mathbf{I R} \\
\left(\mathbf{c m ~ h}^{-1}\right)\end{array}$} & \multicolumn{4}{|c|}{ Soil moisture characteristics } & \multicolumn{4}{|c|}{ Particle size distribution (\%) } \\
\hline & & & $\begin{array}{l}\text { FC } \\
(\%)\end{array}$ & $\begin{array}{l}\text { WP } \\
(\%)\end{array}$ & $\begin{array}{l}\text { AW } \\
(\%)\end{array}$ & $\begin{array}{c}\text { BD } \\
\left(\mathrm{kg} \mathrm{m}^{-3}\right)\end{array}$ & Sand & Silt & Clay & $\begin{array}{c}\text { Soil } \\
\text { texture }\end{array}$ \\
\hline $0-20$ & \multirow{3}{*}{0.49} & \multirow{3}{*}{0.71} & 41.6 & 21.5 & 20.1 & 1.21 & 16.6 & 31.2 & 52.2 & Clayey \\
\hline $20-40$ & & & 42.0 & 21.1 & 20.9 & 1.32 & 16.7 & 31.9 & 51.4 & Clayey \\
\hline $40-60$ & & & 42.2 & 21.2 & 21.0 & 1.37 & 16.8 & 32.1 & 51.1 & Clayey \\
\hline
\end{tabular}

Where: K, IR,FC, WP, AW, and BD represents hydraulic conductivity, infiltration rate,

field capacity, wilting point, available water and bulk density, respectively.

Plant sampling and analysis

At the harvest, plants were taken from all plots to measure grain yield ( $\mathrm{Mg}$ $\left.\mathrm{fed}^{-1}\right)$, stalk yield $\left(\mathrm{Mg} \mathrm{fed}^{-1}\right)$ and calculate NPK-uptake in both maize grains and stalks. NPK concentrations were determined according to Page et al., (1982). Harvest Index (HI; \%) was calculated as follows:

$$
\mathrm{HI}(\%)=(\text { grain yield/grain }+ \text { straw yield }) \times 100
$$

\section{Statistical analyses}

The obtained results were subjected to analyses of variance according to the procedure outlined by Gomez and Gomez (1984) and significant differences were weighted by LSD test at 0.05 and 0.01 levels of probability.

Soil chemical properties

\section{Results and Discussion}

Soil salinity $(E C e)$

The application of organic amendments alone or combination with magnetic iron ore had a highly significant effect on decreasing soil salinity after harvesting of plants during the two growing seasons (Table 4). Consequently, soil salinity as affected by treatments can be arranged in descending order $\mathrm{B}+\mathrm{C}+\mathrm{M}>\mathrm{C}+\mathrm{M}>\mathrm{B}+\mathrm{C}>\mathrm{B}+\mathrm{M}>\mathrm{M}>\mathrm{C}>\mathrm{B}>$ control. The soil salinity was decreased due to biochar and compost tea may sorb salts and mitigate salt stress to plants through salt sorption as reported by Thomas et al. (2013).

\section{Soil sodicity}

Table 4 indicated that sodium adsorption ratio (SAR) and exchangeable sodium percentage (ESP) of the soil were highly significant decreased due to either application of organic amendments alone or mixed with magnetic iron ore during the two growing seasons. The greatest decrease compared to the control was SAR $(-41.81 \%)$ and ESP $(-46.96 \%)$, due to combination between organic amendments and magnetic iron ore as shown in Table 5. It recorded similar results as reported by Sarwar et al. (2008) and Amer et al. (2016). On the other hand, SAR and ESP recorded the highest decrease values ($31.41 \%$ and $-29.16 \%$ respectively) in case of magnetic iron ore application during the two growing seasons. Consequently, the effect of treatments of SAR and ESP values could be arranged in the descending order $\mathrm{B}+\mathrm{C}+\mathrm{M}>\mathrm{C}+\mathrm{M}>\mathrm{B}+\mathrm{C}>\mathrm{B}+\mathrm{M}>\mathrm{B}>\mathrm{C}>\mathrm{M}>$ control. From current study, the magnetic iron ore plays an important role in increasing the solubility of salts and then the removal from the soils. Removal of excess salts or decreasing their activity is necessary for increasing the productivity of salt affected soils. 
Table 4 showed that the soil salinity and sodicity were highly significant increased with the soil depth. This indicates that the removal of soluble salts from soil surface was more than subsurface ones. The only exception is exchangeable calcium, which showed an opposite trend. This may be attributed to the favorable effect of amendments on the leaching ability through improving the physical properties of the soil. Increased salinity with soil depth is in agreement with the findings of El-Missiry (2001) who reported that some of the leached salts from surface layers accumulate in the subsurface ones due to leaching. It is reported also that, organic amendments can enhance the exchangeable calcium (Anand, 1992).

\section{Soil cation exchange capacity (CEC)}

Regarding the effect of organic amendments and magnetic iron ore application on soil CEC after harvesting of maize and wheat, data pointed out that soil CEC values were highly significant increased due to individual application of biochar or compost tea or magnetic iron ore (Table 4). The relative change of CEC recorded the highest value $+18.86 \%$ by combination application between biochar, compost tea and magnetic iron ore during both seasons as shown in Table (5). With respect to the effect of treatments on soil cation exchange capacity, it could be arranged in the following descending order $\mathrm{B}+\mathrm{C}+$ $\mathrm{M}>\mathrm{B}+\mathrm{C}>\mathrm{C}+\mathrm{M}>\mathrm{B}+\mathrm{M}>\mathrm{C}>\mathrm{B}>\mathrm{M}>$ control. Ouedraogo et al. (2001) proved that compost amendment resulted in an increase of CEC due to input of stabilized organic matter being rich in functional groups into soil. Soil organic matter also contributes about $20-70 \%$ to the CEC of many soils. Similar results of this study were found by Amer et al. (2016).

TABLE 4. Some soil chemical characteristics including soil salinity (EC), sodium adsorption ratio (SAR), exchangeable sodium percent (ESP) cation exchange capacity (CEC) as affected by organic amendments and magnetic iron ore application after harvesting of maize and wheat.

\begin{tabular}{|c|c|c|c|c|c|c|c|c|}
\hline \multirow{2}{*}{ Treatments } & \multicolumn{2}{|c|}{$\mathbf{E C}\left(\mathbf{d S} \mathbf{m}^{-1}\right)$} & \multicolumn{2}{|c|}{ SAR (\%) } & \multicolumn{2}{|c|}{$\operatorname{ESP}(\%)$} & \multicolumn{2}{|c|}{$\begin{array}{c}\text { CEC (meq.100 g } \\
\text { soil }^{-1} \text { ) }\end{array}$} \\
\hline & $1^{\mathrm{st}}$ & $2^{\text {nd }}$ & $1^{\mathrm{st}}$ & $2^{\text {nd }}$ & $1^{\mathrm{st}}$ & $2^{\text {nd }}$ & $1^{\text {st }}$ & $2^{\text {nd }}$ \\
\hline Control & $9.90 \mathrm{a}$ & $9.67 \mathrm{a}$ & $14.39 \mathrm{a}$ & $14.62 \mathrm{a}$ & $16.57 \mathrm{a}$ & $16.80 \mathrm{a}$ & $38.31 \mathrm{~g}$ & $37.82 \mathrm{~g}$ \\
\hline Biochar(B) & \begin{tabular}{|l|}
$9.02 b$ \\
\end{tabular} & $9.07 \mathrm{~b}$ & $9.95 \mathrm{~d}$ & $9.46 \mathrm{~d}$ & $11.28 \mathrm{~d}$ & $11.26 \mathrm{~d}$ & $40.45 \mathrm{e}$ & $40.56 \mathrm{e}$ \\
\hline Compost tea (C) & $8.94 \mathrm{c}$ & $8.97 \mathrm{c}$ & $10.29 \mathrm{c}$ & $9.61 \mathrm{c}$ & $11.45 \mathrm{c}$ & $11.44 \mathrm{c}$ & $40.78 \mathrm{~d}$ & $41.14 d$ \\
\hline $\begin{array}{l}\text { Magnetic iron } \\
\text { ore(M) }\end{array}$ & $8.71 \mathrm{~d}$ & $8.68 \mathrm{~d}$ & $10.67 \mathrm{~b}$ & $9.95 b$ & $11.82 \mathrm{~b}$ & $11.82 \mathrm{~b}$ & $39.91 \mathrm{f}$ & $39.93 f$ \\
\hline $\mathrm{B}+\mathrm{C}$ & $8.58 \mathrm{f}$ & $8.58 \mathrm{f}$ & $9.47 \mathrm{f}$ & $8.21 \mathrm{f}$ & $9.79 \mathrm{f}$ & $9.79 \mathrm{f}$ & $42.18 b$ & $42.83 \mathrm{~b}$ \\
\hline $\mathrm{B}+\mathrm{M}$ & $8.64 \mathrm{e}$ & $8.55 \mathrm{e}$ & $9.62 \mathrm{e}$ & $8.32 \mathrm{e}$ & $9.90 \mathrm{e}$ & $9.91 \mathrm{e}$ & $40.84 d$ & $41.29 \mathrm{~d}$ \\
\hline $\mathrm{C}+\mathrm{M}$ & $8.47 \mathrm{~g}$ & $8.43 \mathrm{~g}$ & $9.43 \mathrm{~g}$ & $8.11 \mathrm{~g}$ & $9.67 \mathrm{~g}$ & $9.67 \mathrm{~g}$ & $41.12 \mathrm{c}$ & $41.60 \mathrm{c}$ \\
\hline $\mathrm{B}+\mathrm{C}+\mathrm{M}$ & $7.74 \mathrm{~h}$ & $7.63 \mathrm{~h}$ & $8.21 \mathrm{~h}$ & $7.45 \mathrm{~h}$ & $8.84 \mathrm{~h}$ & $8.86 \mathrm{~h}$ & $44.24 \mathrm{a}$ & $46.25 \mathrm{a}$ \\
\hline $\mathrm{F}_{\text {test }}$ & ** & $* *$ & $* *$ & $* *$ & $* *$ & *** & $* *$ & *** \\
\hline $\mathrm{LSD}_{0.05}$ & 0.01 & 0.06 & 0.003 & 0.02 & 0.002 & 0.041 & 0.144 & 0.14 \\
\hline $\mathrm{LSD}_{0.01}$ & \begin{tabular}{|l|}
0.015 \\
\end{tabular} & 0.08 & 0.004 & 0.029 & 0.003 & 0.032 & 0.104 & 0.20 \\
\hline 0 -20cm depth & $8.26 \mathrm{c}$ & $8.11 \mathrm{c}$ & $9.4 \mathrm{c}$ & $8.65 \mathrm{c}$ & $10.26 \mathrm{c}$ & $10.29 \mathrm{c}$ & $41.43 \mathrm{a}$ & $41.85 \mathrm{a}$ \\
\hline 20-40cm depth & $8.70 \mathrm{~b}$ & $8.71 \mathrm{~b}$ & $10.38 \mathrm{~b}$ & $9.59 \mathrm{~b}$ & $11.3 \mathrm{~b}$ & $11.33 \mathrm{~b}$ & $40.78 \mathrm{~b}$ & $41.40 \mathrm{~b}$ \\
\hline $40-60 \mathrm{~cm}$ depth & $9.29 \mathrm{a}$ & $9.27 \mathrm{a}$ & $10.98 \mathrm{a}$ & $10.16 \mathrm{a}$ & $11.93 \mathrm{a}$ & $11.96 \mathrm{a}$ & $40.29 \mathrm{c}$ & $41.03 \mathrm{c}$ \\
\hline $\mathrm{F}_{\text {test }}$ & $* *$ & $* *$ & $* *$ & $* *$ & $* *$ & $* *$ & ** & ** \\
\hline $\mathrm{LSD}_{0.05}$ & \begin{tabular}{|l|}
0.007 \\
\end{tabular} & 0.20 & 0.001 & 0.047 & 0.002 & 0.023 & 0.08 & 0.07 \\
\hline $\mathrm{LSD}_{0.01}$ & \begin{tabular}{|l|}
0.009 \\
\end{tabular} & 0.28 & 0.002 & 0.048 & 0.003 & 0.055 & 0.07 & 0.10 \\
\hline
\end{tabular}

Egypt. J. Soil Sci. 56, No.1 (2016) 
TABLE 5. Relative change ( $\pm \%$ ) of some soil chemical characteristics as affected by organic amendments and magnetic iron ore application after harvesting of crops (over mean values of the two growing seasons).

\begin{tabular}{|c|c|c|c|c|}
\hline Treatments & $\begin{array}{l}\text { Relative } \\
\text { change in } \\
\text { EC }( \pm \%)\end{array}$ & $\begin{array}{c}\text { Relative } \\
\text { change in } \\
\text { SAR } \\
( \pm \%)\end{array}$ & $\begin{array}{c}\text { Relative } \\
\text { change in } \\
\operatorname{ESP}( \pm \%)\end{array}$ & $\begin{array}{c}\text { Relative } \\
\text { change in } \\
\text { CEC } \\
( \pm \%)\end{array}$ \\
\hline Control & 9.78 & 14.50 & 16.68 & 38.06 \\
\hline Biochar(B) & -7.56 & -34.75 & -32.45 & +5.70 \\
\hline Compost tea $(\mathrm{C})$ & -8.48 & -33.71 & -31.41 & +7.68 \\
\hline Magnetic iron ore (M) & -11.24 & -31.40 & -29.16 & +4.49 \\
\hline $\mathrm{B}+\mathrm{C}$ & -12.31 & -43.40 & -41.32 & +11.66 \\
\hline $\mathrm{B}+\mathrm{M}$ & -12.21 & -34.54 & -40.64 & +7.37 \\
\hline $\mathrm{C}+\mathrm{M}$ & -13.64 & -36.57 & -42.04 & +8.66 \\
\hline $\mathrm{B}+\mathrm{C}+\mathrm{M}$ & -21.46 & -41.81 & -46.96 & +18.86 \\
\hline
\end{tabular}

Soil physical properties

Soil bulk density $(B D)$ and its porosity

The application of organic amendments alone or mixed with magnetic iron ore led to highly significant increase of the soil porosity and due to this effect bulk density was decreased (Table 6). It could be summarized the relative change of some physical characteristics of the soil in Table 7. Data showed that the lowest values of soil bulk density and the highest values of porosity were obtained by application of biochar + compost tea + magnetic iron ore after harvesting of maize and wheat plants. These results may be attributed to the role of biochar, which it had low density material that helps to lower the bulk density of highly clay soils, increasing drainage and aeration. This positive effect of biochar on soil density has been reported by previous studies (Laird et al., 2010). It is worth to mention that, the decrease in bulk density due to biochar was due to the fact that biochar itself has substantially a lower bulk density and higher porosity than the mineral particles (Karer et al., 2013). Biochar also may be have some beneficial effects on nutrient cycling, water retention, reduced soil compaction, increased soil aeration such material serves as cementing agents and ultimately improved crop yield.

Infiltration rate (IR) and hydraulic conductivity $(K)$

Regarding the soil infiltration rate and its hydraulic conductivity, the data in Table 6 showed that these parameters were increased due to the application of biochar, compost tea and magnetic iron ore alone or mixed both of them due to the increasing in soil porosity. Similar results were confirmed by Sarwar et al. (2008). On the other hand, Barnes et al. (2014) found that hydraulic conductivity high significant increased in clay-rich soil due to biochar application. Data also pointed that, infiltration rate and hydraulic conductivity recorded highest values by combination of organic amendments and magnetic iron ore application after harvesting of maize and wheat as reported by Ouyang et al. (2013). 
TABLE 6. Some soil physical characteristics as affected by organic amendments and magnetic iron ore application after harvesting of maize and wheat.

\begin{tabular}{|c|c|c|c|c|c|c|c|c|}
\hline \multirow{2}{*}{ Treatments } & \multicolumn{4}{|c|}{$1^{\text {st }}$ season } & \multicolumn{4}{|c|}{$2^{\text {nd }}$ season } \\
\hline & $\begin{array}{c}\text { BD } \\
\left(\mathbf{M g ~ m}^{-3}\right)\end{array}$ & $\begin{array}{c}\text { Porosity } \\
(\%)\end{array}$ & $\underset{\left(\mathrm{cm} \mathrm{h}^{-1}\right)}{\mathrm{IR}}$ & $\underset{\left(\mathbf{m ~ d}^{-\mathbf{1}}\right)}{\mathbf{K}}$ & $\left|\begin{array}{c}\mathbf{B D} \\
\left(\mathbf{M g ~ m}^{-3}\right)\end{array}\right|$ & $\begin{array}{c}\text { Porosity } \\
(\%)\end{array}$ & $\underset{\left(\mathrm{cm} \mathrm{h}^{-1}\right)}{\mathrm{IR}}$ & $\underset{\left(\mathbf{m ~ d}^{-\mathbf{1}}\right)}{\mathbf{K}}$ \\
\hline Control & $1.43 \mathrm{a}$ & $47.01 \mathrm{~g}$ & $0.70 \mathrm{f}$ & $0.47 \mathrm{~d}$ & $1.44 \mathrm{a}$ & $47.04 \mathrm{~h}$ & $0.72 \mathrm{~g}$ & $0.47 \mathrm{e}$ \\
\hline Biochar(B) & $1.34 \mathrm{~d}$ & $47.50 \mathrm{~d}$ & $0.78 \mathrm{~d}$ & $0.48 \mathrm{c}$ & $1.35 \mathrm{~d}$ & $47.56 \mathrm{e}$ & $0.80 \mathrm{e}$ & $0.48 \mathrm{~d}$ \\
\hline Compost tea $(\mathrm{C})$ & $1.36 \mathrm{c}$ & $47.30 \mathrm{e}$ & $0.78 \mathrm{~d}$ & $0.48 \mathrm{c}$ & $1.34 \mathrm{c}$ & $47.33 \mathrm{f}$ & $0.80 \mathrm{e}$ & $0.48 \mathrm{~d}$ \\
\hline $\begin{array}{l}\text { Magnetic iron } \\
\text { ore(M) }\end{array}$ & $\mathrm{b}$ & 47 & $0.73 \mathrm{e}$ & 0. & 1. & 47.1 & $0.74 \mathrm{f}$ & $0.47 \mathrm{e}$ \\
\hline $\mathrm{B}+\mathrm{C}$ & $1.32 \mathrm{f}$ & $47.65 b$ & $0.83 \mathrm{c}$ & $0.50 \mathrm{~b}$ & $1.31 \mathrm{f}$ & $47.65 \mathrm{c}$ & $0.85 d$ & $0.49 \mathrm{c}$ \\
\hline $\mathrm{B}+\mathrm{M}$ & $1.33 \mathrm{e}$ & $47.60 \mathrm{c}$ & $0.84 \mathrm{bc}$ & $0.50 \mathrm{~b}$ & $1.33 \mathrm{e}$ & $47.61 \mathrm{~d}$ & $0.86 \mathrm{c}$ & $0.50 \mathrm{~b}$ \\
\hline $\mathrm{C}+\mathrm{M}$ & $1.32 \mathrm{f}$ & $47.65 \mathrm{~b}$ & $0.85 \mathrm{~b}$ & $0.50 \mathrm{~b}$ & $1.31 \mathrm{f}$ & $47.72 \mathrm{~b}$ & $0.88 b$ & $0.50 \mathrm{~b}$ \\
\hline $\mathrm{B}+\mathrm{C}+\mathrm{M}$ & $1.30 \mathrm{~g}$ & $47.80 \mathrm{a}$ & $0.92 \mathrm{a}$ & $0.52 \mathrm{a}$ & $1.29 \mathrm{~g}$ & $47.96 \mathrm{a}$ & $0.95 \mathrm{a}$ & $0.52 \mathrm{a}$ \\
\hline $\mathrm{F}_{\text {test }}$ & $* *$ & $* *$ & $* *$ & $* *$ & $* *$ & $* *$ & $* *$ & $* *$ \\
\hline $\mathrm{LSD}_{0.05}$ & 0.003 & 0.031 & 0.011 & 0.011 & 0.003 & 0.031 & 0.009 & 0.007 \\
\hline $\mathrm{LSD}_{0.01}$ & 0.004 & 0.042 & 0.015 & 0.015 & 0.004 & 0.042 & 0.013 & 0.01 \\
\hline
\end{tabular}

Where: K, IR and BD represent hydraulic conductivity, infiltration rate and bulk density, respectively

TABLE 7. Relative change ( $\pm \%$ ) of some soil physical characteristics as affected by organic amendments and magnetic iron ore application after harvesting of crops (mean values of 2 seasons).

\begin{tabular}{|c|c|c|c|c|}
\hline Treatments & $\begin{array}{l}\text { Relative } \\
\text { change in } \\
\operatorname{BD}( \pm \%)\end{array}$ & $\begin{array}{c}\text { Relative } \\
\text { change in } \\
\text { porosity }( \pm \\
\%)\end{array}$ & $\begin{array}{c}\text { Relative } \\
\text { change in } \\
\text { IR }( \pm \%)\end{array}$ & $\begin{array}{c}\text { Relative } \\
\text { change in } K \\
( \pm \%)\end{array}$ \\
\hline Control & 1.44 & 47.03 & 0.71 & 0.47 \\
\hline Biochar (B) & -6.27 & +1.07 & +11.27 & +2.13 \\
\hline Compost tea (C) & -5.92 & +0.62 & +11.27 & +2.13 \\
\hline $\begin{array}{l}\text { Magnetic iron } \\
\text { ore (M) }\end{array}$ & -2.79 & +0.20 & +3.52 & 0.00 \\
\hline $\mathrm{B}+\mathrm{C}$ & -8.36 & +1.33 & +18.31 & +5.32 \\
\hline $\mathrm{B}+\mathrm{M}$ & -7.32 & +1.23 & +19.72 & +6.38 \\
\hline $\mathrm{C}+\mathrm{M}$ & -8.36 & +1.40 & +21.83 & +6.38 \\
\hline $\mathrm{B}+\mathrm{C}+\mathrm{M}$ & -9.76 & +1.82 & +31.69 & +10.64 \\
\hline
\end{tabular}

\section{Available macronutrients}

The data representing availability of soil nutrients ( $\mathrm{N}, \mathrm{P}$ and $\mathrm{K}$ ) after wheat and maize harvesting are shown in Table 8. Statistical analyses of interaction showed that soil nutrients availability ( $\mathrm{N}, \mathrm{P}$ and $\mathrm{K}$ ) was highly significant increased due to all treatments used compared to the control; this trend was true for both crops. Furthermore, application of biochar, compost tea enriched by magnetic iron was significantly superior for both crops. Application of biochar,

Egypt. J. Soil Sci. 56, No.1 (2016) 
compost tea, magnetic individually or together highly significant increased the availability of nitrogen, phosphorus and potassium. It could be arranged this effect in the following order over mean of the two seasons; for $\mathrm{N}$ nutrient: $\mathrm{B}+\mathrm{C}$ $+\mathrm{M}>\mathrm{B}+\mathrm{C}>\mathrm{B}+\mathrm{M}>\mathrm{C}+\mathrm{M}>\mathrm{B}>\mathrm{C}>\mathrm{M}>$ control; for $\mathrm{P}$ availability: $\mathrm{B}+\mathrm{C}+\mathrm{M}>$ $\mathrm{B}+\mathrm{M} \approx \mathrm{B}+\mathrm{C}>\mathrm{M}+\mathrm{C} \approx \mathrm{B}>\mathrm{C} \approx \mathrm{M}>$ control and for $\mathrm{K}$ element: $\mathrm{B}+\mathrm{C}+\mathrm{M}>$ $\mathrm{B}+\mathrm{M} \approx \mathrm{B}+\mathrm{C}>\mathrm{M}+\mathrm{C} \approx \mathrm{B}>\mathrm{C} \approx \mathrm{M}>$ control. These results were in agreement with Sarwar et al. (2008) who found that soil $\mathrm{pH}$ was lowered and SAR decreased due to acidic effect of compost, formation of acids, release of $\mathrm{Ca}$ and leaching of $\mathrm{Na}$. Hence, available amount of all the macro plant nutrients $(\mathrm{N}, \mathrm{P}, \mathrm{K}, \mathrm{Ca}$ and $\mathrm{Mg}$ ) and organic matter content increased in the soil. These results may be attributed to the role of biochar and compost tea application to soil which influences nutrient retention and its availability were enhanced after biochar application (Glaser et al., 2002). Biochar could adsorb anions and cations to prevent leaching of applied nutrients (Major et al., 2009).

TABLE 8. Available macronutrients, nitrogen, phosphorus and potassium $\left(\mathrm{mgkg}^{-1}\right)$ after harvesting during the two growing seasons.

\begin{tabular}{|c|c|c|c|c|c|c|}
\hline \multirow[b]{2}{*}{ Treatments } & \multicolumn{3}{|c|}{$\begin{array}{l}\text { Available soil nutrients } \\
\text { after harvesting of maize } \\
\left(\mathrm{mgkg}^{-1}\right) \text { in } 1^{\text {st }} \text { season }\end{array}$} & \multicolumn{3}{|c|}{$\begin{array}{l}\text { Available soil nutrients after } \\
\text { harvesting of wheat }\left(\mathrm{mgkg}^{-1}\right) \\
\text { in } 2^{\text {nd }} \text { season }\end{array}$} \\
\hline & $\mathbf{N}$ & $\mathbf{P}$ & $\mathbf{K}$ & $\mathbf{N}$ & $\mathbf{P}$ & $\mathbf{K}$ \\
\hline Control & $26.0 \mathrm{~g}$ & $11.0 \mathrm{e}$ & $256.0 \mathrm{f}$ & $26.1 \mathrm{~h}$ & $11.1 \mathrm{e}$ & $258.1 \mathrm{~h}$ \\
\hline Biochar(B) & $32.7 \mathrm{~d}$ & $13.0 \mathrm{c}$ & $264.3 \mathrm{c}$ & $33.1 \mathrm{e}$ & $13.1 \mathrm{c}$ & $265.1 d$ \\
\hline Compost tea (C) & $31.0 \mathrm{e}$ & $12.0 \mathrm{~d}$ & $263.0 \mathrm{~d}$ & $31.1 \mathrm{f}$ & $12.2 \mathrm{~d}$ & $263.2 f$ \\
\hline $\begin{array}{l}\text { Magnetic iron } \\
\text { ore(M) }\end{array}$ & $27.5 f$ & $12.0 \mathrm{~d}$ & $257.0 \mathrm{e}$ & $28.1 \mathrm{~g}$ & $12.1 \mathrm{~d}$ & $260.1 \mathrm{~g}$ \\
\hline $\mathrm{B}+\mathrm{C}$ & $36.0 \mathrm{a}$ & $14.0 \mathrm{~b}$ & $266.7 \mathrm{~b}$ & $36.1 \mathrm{~b}$ & $14.6 \mathrm{~b}$ & $267.1 \mathrm{c}$ \\
\hline $\mathrm{B}+\mathrm{M}$ & $35.0 \mathrm{~b}$ & $14.0 \mathrm{~b}$ & $266.7 \mathrm{~b}$ & $35.1 \mathrm{c}$ & $14.6 \mathrm{~b}$ & $268.1 b$ \\
\hline $\mathrm{M}+\mathrm{C}$ & $34.0 \mathrm{c}$ & $13.0 \mathrm{c}$ & $264.0 \mathrm{c}$ & $34.1 \mathrm{~d}$ & $13.3 \mathrm{c}$ & $264.1 \mathrm{e}$ \\
\hline $\mathrm{B}+\mathrm{C}+\mathrm{M}$ & $36.0 \mathrm{a}$ & $14.8 \mathrm{a}$ & $270.4 \mathrm{a}$ & $39.1 \mathrm{a}$ & $16.1 \mathrm{a}$ & $275.1 \mathrm{a}$ \\
\hline $\mathrm{F}_{\text {test }}$ & $* *$ & $* *$ & $* *$ & $* *$ & $* *$ & $* *$ \\
\hline $\mathrm{LSD}_{0.05}$ & 0.46 & 0.17 & 0.61 & 0.24 & 0.32 & 0.31 \\
\hline $\mathrm{LSD}_{0.01}$ & 0.64 & 0.34 & 0.84 & 0.34 & 0.44 & 0.43 \\
\hline
\end{tabular}

Yield of maize and wheat

Figures 1 and 2 argued that application of biochar, compost tea, magnetic iron ore individually or together high significant increased the yield of wheat and maize. The results outlined some differences in yield and harvest index induced by biochar application alone or combination with compost tea and magnetic iron ore. The treatment amended with biochar+ compost tea + magnetic iron ore application seemed to have higher values, as compared all other treatments used. The ameliorative role of the previous amendments in salt affected soils may be attributed to these materials increase the tolerance of plants to salinity at physiological growth stages and improve some soil proprieties. Similar results were obtained by Hussain et al. (2001), Poraas et al. (2008) and Getachew et al. (2015). 


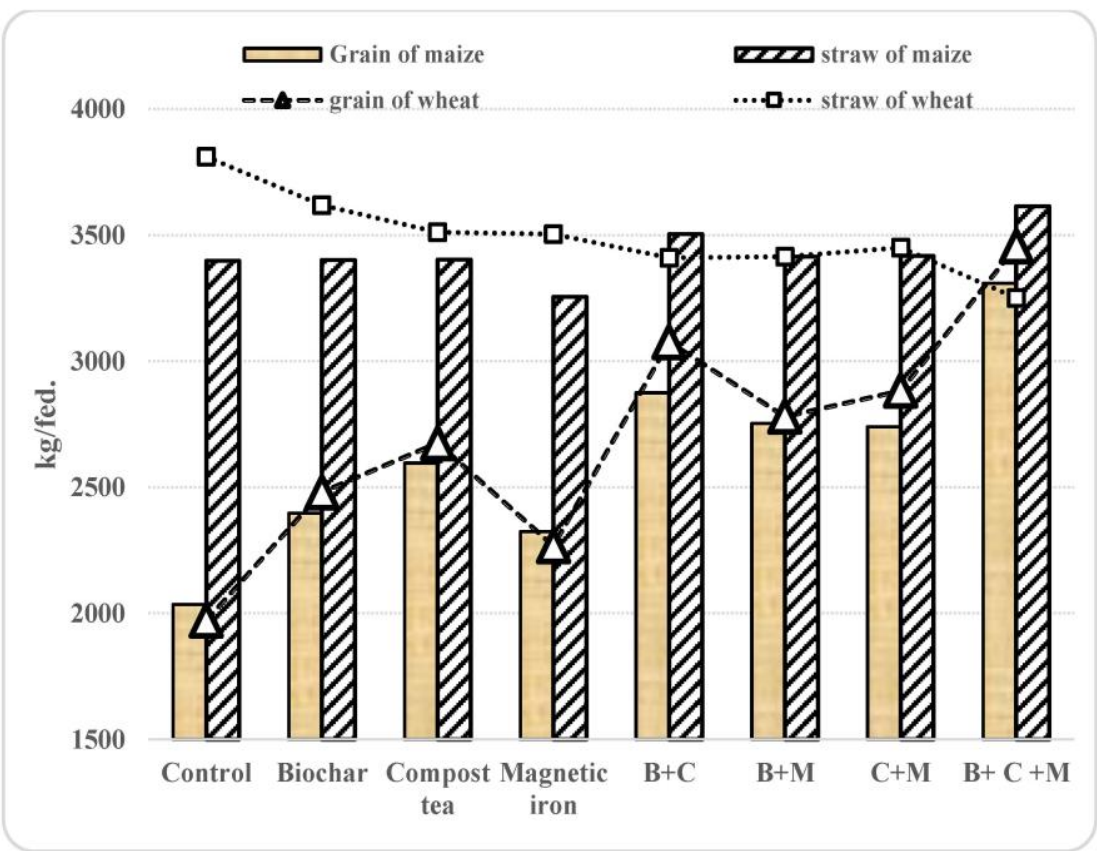

Fig. 1. Yield of maize and wheat as affected by biochar, compost tea and magnetic iron ore application.

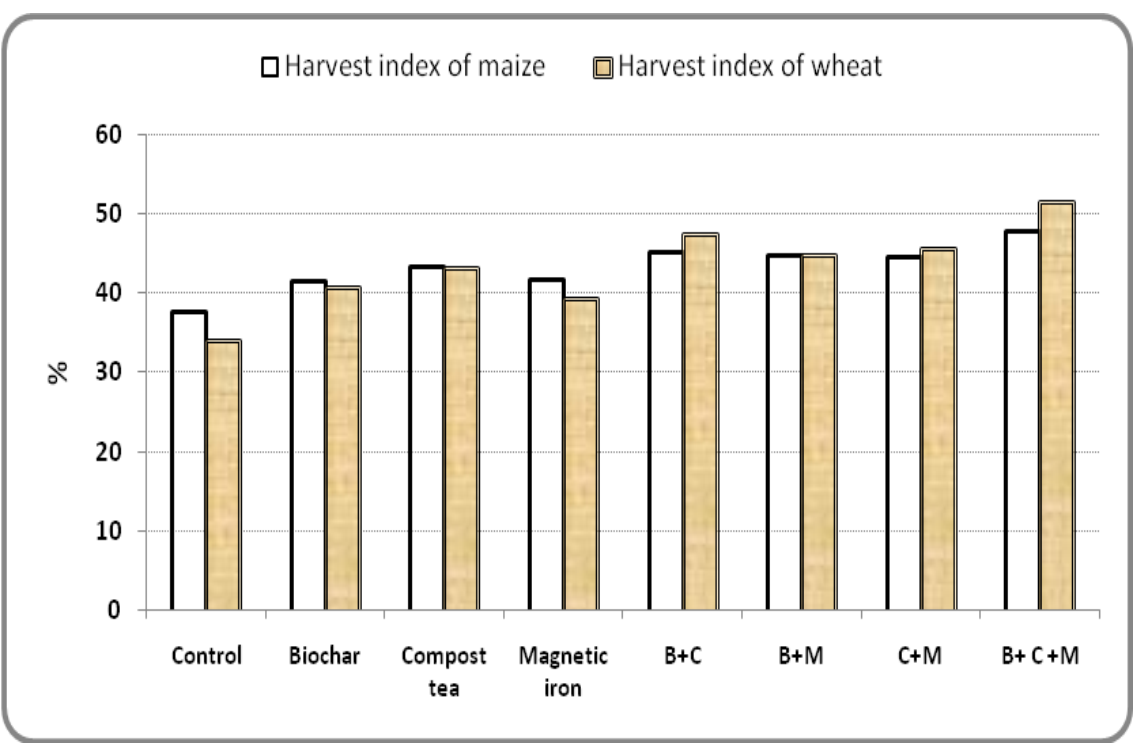

Fig. 2. Harvest index of maize and wheat as affected by biochar, compost tea and magnetic iron ore application.

Egypt. J. Soil Sci. 56, No.1 (2016) 
Field water use efficiency ( $F W U E)$

Table 9 showed that the application of biochar and compost extract as organic amendments alone or mixed with magnetic iron ore had a highly significant effect on increasing field water use efficiency Data showed that field water use efficiency for grain and straw of maize and wheat was recorded the highest values under application of biochar + compost + magnetic iron ore. These results may be attributed to the role of biochar and compost in improved crop yield (Karer, et al. 2013) and this may due to magnetic iron ore that contain macronutrients such as $\mathrm{Zn}, \mathrm{Fe}$ and $\mathrm{Mn}$ or due to that magnetic iron ore alleviated the bad effect of soil salinity and improved some soil properties and productivity under salt affected soils.

TABLE 9. Field water use efficiency (FWUE) for maize and wheat as affected by organic amendments and magnetic iron ore application.

\begin{tabular}{|l|c|c|c|c|}
\hline \multirow{2}{*}{ Treatments } & \multicolumn{2}{|c|}{ FWUE of maize } & \multicolumn{2}{c|}{ FWUE of wheat } \\
\cline { 2 - 5 } & Grain $\left(\mathbf{k g ~ m}^{-3}\right)$ & Straw $\left(\mathbf{k g ~ m}^{-\mathbf{3}}\right)$ & Grain $\left(\mathbf{k g ~ m}^{-3}\right)$ & Straw $\left(\mathbf{k g ~ m}^{-3}\right)$ \\
\hline Control & & & & \\
\hline Biochar(B) & $0.61 \mathrm{~h}$ & $0.96 \mathrm{a}$ & $0.88 \mathrm{~h}$ & $1.63 \mathrm{a}$ \\
\hline Compost $(\mathrm{C})$ & $0.72 \mathrm{f}$ & $0.91 \mathrm{c}$ & $1.11 \mathrm{f}$ & $1.55 \mathrm{~b}$ \\
\hline $\begin{array}{l}\text { Magnetic iron } \\
\text { ore(M) }\end{array}$ & $0.78 \mathrm{e}$ & $0.90 \mathrm{c}$ & $1.20 \mathrm{e}$ & $1.51 \mathrm{c}$ \\
\hline $\mathrm{B}+\mathrm{C}$ & $0.70 \mathrm{~g}$ & $0.87 \mathrm{~d}$ & $1.02 \mathrm{~g}$ & $1.51 \mathrm{c}$ \\
\hline $\mathrm{B}+\mathrm{M}$ & $0.86 \mathrm{~b}$ & $0.91 \mathrm{c}$ & $1.38 \mathrm{~b}$ & $1.47 \mathrm{e}$ \\
\hline $\mathrm{C}+\mathrm{M}$ & $0.83 \mathrm{c}$ & $0.91 \mathrm{c}$ & $1.25 \mathrm{~d}$ & $1.47 \mathrm{e}$ \\
\hline $\mathrm{B}+\mathrm{C}+\mathrm{M}$ & $0.82 \mathrm{~d}$ & $0.91 \mathrm{c}$ & $1.30 \mathrm{c}$ & $1.48 \mathrm{~d}$ \\
\hline $\mathrm{F}_{\text {test }}$ & $0.99 \mathrm{a}$ & $0.93 \mathrm{~b}$ & $1.55 \mathrm{a}$ & $1.40 \mathrm{f}$ \\
\hline $\mathrm{LSD}_{0.05}$ & $* *$ & $* *$ & $* *$ & $* *$ \\
\hline $\mathrm{LSD}_{0.01}$ & 0.003 & 0.006 & 0.007 & 0.006 \\
\hline
\end{tabular}

\section{Nutrients status}

Nitrogen, phosphorus and potassium uptake of maize and wheat was highly significant increased due to the application of different treatments (Table 10). Data showed that uptake of nutrients had positive effect due to compost tea and biochar application during the two growing seasons. The results also pointed out that nutrient uptake recorded highest values by biochar + compost tea + magnetic iron ore application comparing with the other treatments. These results may be attributed to the role of biochar, compost tea and magnetic iron ore on increasing the dry weight of maize and wheat yields hence recorded highest values of nutrient uptake of maize and wheat plants. The role of biochar as soil conditioner reflects on the retention and mobilization of existing nutrients for plant uptake improving soil functions by reducing nutrient loss below the root zone as well as increasing the bioavailability of nutrients to plants. 
TABLE 10. Nutrients uptake by both maize and wheat plants.

\begin{tabular}{|c|c|c|c|c|c|c|}
\hline \multirow[b]{2}{*}{ Treatments } & \multicolumn{3}{|c|}{$\begin{array}{c}\text { Nutrient uptake by maize } \\
\text { plant } \\
\left(\mathrm{kg} \mathrm{fed}^{-1}\right)\end{array}$} & \multicolumn{3}{|c|}{$\begin{array}{c}\text { Nutrient uptake by wheat } \\
\text { plant } \\
\left(\mathrm{kg} \mathrm{fed}^{-1}\right)\end{array}$} \\
\hline & $\mathrm{N}$ & $\mathrm{P}$ & $\mathrm{K}$ & $\mathrm{N}$ & $\mathrm{P}$ & $\mathrm{K}$ \\
\hline Control & $53.2 \mathrm{~h}$ & $9.44 \mathrm{~g}$ & $57.6 \mathrm{f}$ & $40.5 \mathrm{~h}$ & $9.3 \mathrm{~h}$ & $53.9 \mathrm{e}$ \\
\hline Biochar(B) & $58.2 \mathrm{f}$ & $10.71 \mathrm{e}$ & $56.4 \mathrm{~g}$ & $49.5 \mathrm{f}$ & $12.0 \mathrm{f}$ & $57.45 \mathrm{c}$ \\
\hline Compost tea (C) & $61.3 \mathrm{e}$ & $11.55 \mathrm{~d}$ & $58.6 \mathrm{e}$ & $52.1 \mathrm{e}$ & $13.0 \mathrm{e}$ & $58.12 \mathrm{~b}$ \\
\hline $\begin{array}{l}\text { Magnetic iron } \\
\text { ore(M) }\end{array}$ & $56.3 \mathrm{~g}$ & $10.39 \mathrm{f}$ & $54.1 \mathrm{~h}$ & $43.5 \mathrm{~g}$ & $11.2 \mathrm{~g}$ & $55.61 d$ \\
\hline $\mathrm{B}+\mathrm{C}$ & $66.0 \mathrm{~b}$ & $12.13 \mathrm{~b}$ & $61.4 \mathrm{~b}$ & $60.73 b$ & $14.6 \mathrm{~b}$ & $59.0 \mathrm{a}$ \\
\hline $\mathrm{B}+\mathrm{M}$ & $64.1 \mathrm{c}$ & $11.76 \mathrm{c}$ & $59.3 \mathrm{c}$ & $53.4 \mathrm{~d}$ & $13.3 \mathrm{~d}$ & $57.36 \mathrm{c}$ \\
\hline $\mathrm{C}+\mathrm{M}$ & $63.0 \mathrm{~d}$ & $11.74 \mathrm{c}$ & $58.9 \mathrm{~d}$ & $55.06 \mathrm{c}$ & $13.7 \mathrm{c}$ & $58.05 \mathrm{~b}$ \\
\hline $\mathrm{B}+\mathrm{C}+\mathrm{M}$ & $72.7 \mathrm{a}$ & $13.42 \mathrm{a}$ & $66.2 \mathrm{a}$ & $69.4 \mathrm{a}$ & $16.6 \mathrm{a}$ & $59.17 \mathrm{a}$ \\
\hline $\mathrm{F}_{\text {test }}$ & $* *$ & $* *$ & $* *$ & $* *$ & $* *$ & $* *$ \\
\hline $\mathrm{LSD}_{0.05}$ & 0.25 & 0.03 & 0.16 & 0.27 & 0.109 & 0.21 \\
\hline $\mathrm{LSD}_{0.01}$ & 0.34 & 0.04 & 0.23 & 0.37 & 0.146 & 0.29 \\
\hline
\end{tabular}

\section{Economical evaluation}

The economical evaluation of any agricultural product is a crucial issue. Data in Fig. 3 and 4 showed that total income and net income were highly significant increased with the application of different treatments. As mentioned before, different previous treatments could ameliorate the saline- soils conditions for cereal crops and production resulting in the highest values of maize and wheat yields, which could lead to the total net income. The net income for previous treatments has recorded the highest values (3869.7 and $6249.5 \mathrm{~L} \mathrm{fed}^{-1}$ ) with combination of the above mentioned treatments, for maize and wheat, respectively. Economical efficiency also took the same trend, since it was recorded the highest values (2.25 and 2.42) by application of biochar, compost tea and magnetic iron ore for maize and wheat, respectively. Consequently, the effect of different treatments on net income of maize values can be arranged in the following order $\mathrm{B}+\mathrm{C}+\mathrm{M}>\mathrm{B}+\mathrm{C}>\mathrm{B}+\mathrm{M}>\mathrm{C}>\mathrm{B}>\mathrm{C}+\mathrm{M}>\mathrm{B}>\mathrm{M}>$ control. Whereas, for wheat: $\mathrm{B}+\mathrm{C}+\mathrm{M}>\mathrm{B}+\mathrm{C}>\mathrm{C}+\mathrm{M}>\mathrm{B}+\mathrm{M}>\mathrm{C}>\mathrm{B}>\mathrm{B}>\mathrm{M}>$ control. Net income from water unit (Net IWU: $\mathrm{LE} \mathrm{m}^{-3}$ ) was high significant increased by application of biochar, compost, magnetic iron ore individual or combination of them. Net income from water unit (NIWU) recorded highest value (1.29 and 3.12 $\mathrm{LE} \mathrm{m}^{-3}$ ) due to application of biochar + compost + magnetic iron ore, for maize and wheat, respectively 


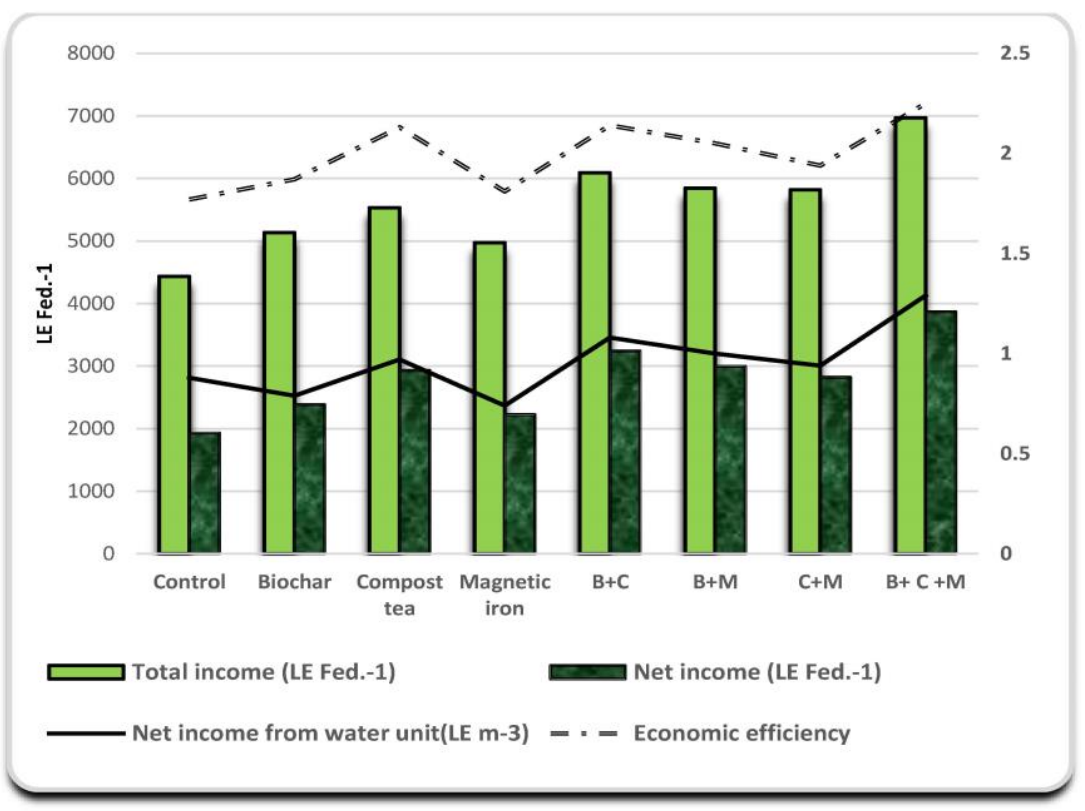

Fig. 3. Total income, net income, net income from water unit and economic efficiency of maize yield.

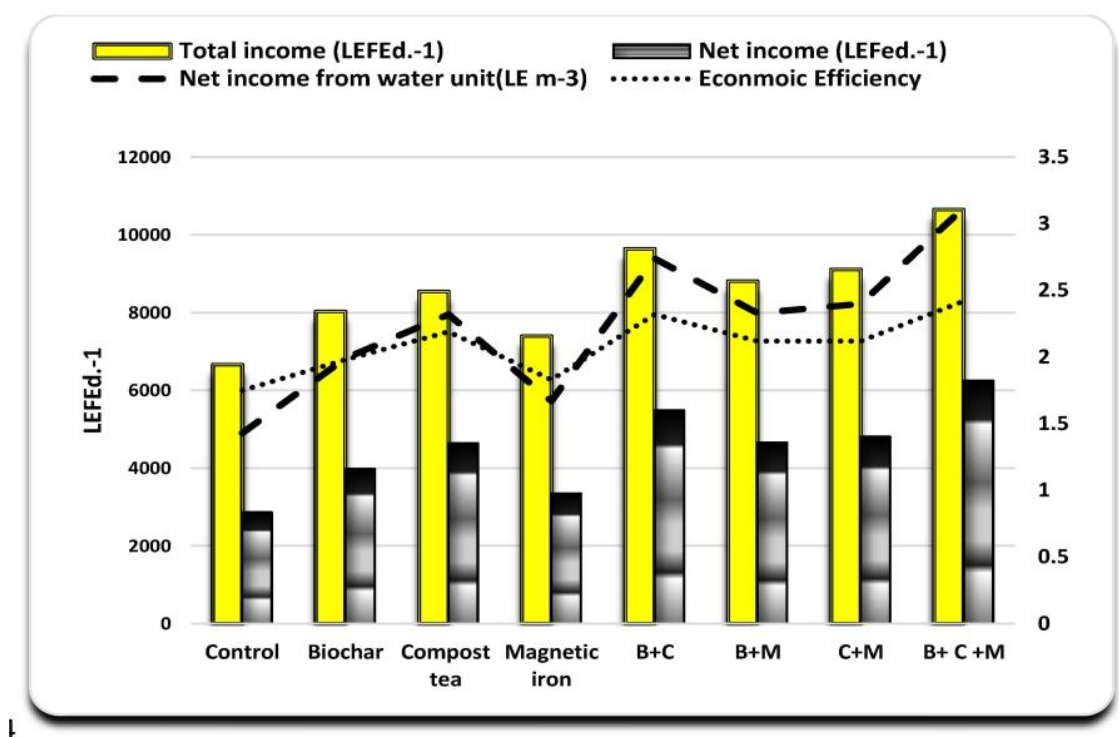

Economical efficiency $=$ total net income $\left(\mathrm{LE} \mathrm{fed}^{-1}\right) /$ total cost $\left(\mathrm{LE} \mathrm{fed}{ }^{-1}\right)$

Net income from water unit $\left(\mathrm{LE} \mathrm{m}^{-3}\right)=$ net income $\left(\mathrm{LE} \mathrm{fed}^{-1}\right) /$ applied water $\left(\mathrm{m}^{3} \mathrm{fed}^{-1}\right)$

Where: the applied water calculated as $3500 \mathrm{~m}^{3} \mathrm{fed}^{-1}$ in first season and $2000 \mathrm{~m}^{3} \mathrm{fed}^{-1}$ in second seasons.

Fig. 4.Total income, net income, net income from water unit and economic efficiency of wheat yield. 


\section{Conclusion}

Farmers practicing rice-wheat system in Egypt particularly and elsewhere in the world generally having similar climatic and soil conditions are recommended to compost the rice, maize and wheat straw coupled with animal manure and other plants residues instead of burning or wasting otherwise. The composts prepared will not only supplement the chemical fertilizers but also reduce the environmental pollution. In this strategy, the cost of production is also reduced. Hence, higher yield with resultantly more income is expected for the farming community in this farming system. The fertility and productivity of the soil could be improved on sustainable basis. It could be concluded that compost tea, biochar amendments as well as magnetic iron ore application could be economically used for production of wheat and maize without adverse effect on crop productivity and soil properties under saline soil conditions.

\section{References}

Alburquerque, J.A., Salazar, P., Barron, V.,Torrent, J., Campillo, MDCD and Gallardo, A. (2012) Enhanced wheat yield by biochar addition under different mineral fertilization levels. Agronomy for Sustainable Development, 33, 475-484.

Amer, M. M., Elhenawy, A. S., Alshaal, T. and El-Ramady, H.R. (2016) Effect of Organic and Inorganic Mixture Applications On Rice Production Under Salt Affected Soil Conditions Plant Nutrition 2016Annual Meeting of the German Society for Plant Nutrition Stuttgart-. hohenheim 28. - 30. September 2016-http://www.dgp

Anand, S. (1992) Effect of organic amendments on the nutrition and yield of wetland and sodic soil reclamation. J. Indian Soc. Soil Sci.40 (4), 816-822.

Barnes, R.T., Gallagher, M.E., Masiello, C.A., Liu, Z. and Dugan, B. (2014) BiocharInduced Changes in Soil Hydraulic Conductivity and Dissolved Nutrient Fluxes Constrained by Laboratory Experiments. PLoS ONE 9(9): e108340. Doi: 10.1371.

Black, G.R. and Hartge,K.H. (1986) Bulk Density," In: A. Klute, et al.( Ed.) Methods of Soil Analysis, Part I, ASA and SSSA, Madison, pp: 363-375.

Brady, N.C. and Weill, R.R. (2004) Elements of the Nature and Properties of Soils. $2^{\text {nd }}$ ed.Pearson Prentice Hall. Upper Saddle River NJ. pp. 111-112.

Brandstaka, T., Helenius, J., Hovi, J., Kivelä, J., Koppelmäki, K., Simojoki, A., Soinne, H. and Tammeorg, P. (2010) Biochar filter: use of biochar in agriculture as soil conditioner, University of Helsinki, Helsinki, Finland. 
Carter, M. R., Sanderson, J. B. and MacLeod, J. A. (2004) Influence of compost on the physical properties and organic matter fractions of a fine sandy loam throughout the cycle of a potato rotation. Canadian J. of Soil Sci., 84, 211-218.

Chan, K. Y., Van Zwieten, L., Meszaros, I. Downie, A.and Joseph. S. (2007) Agronomic values of greenwaste biochar as a soil amendment. Australian J. of Soil Res. 45, 629-634.

Downie, A., Crosky, A. and Munroe, P. (2009) Physical properties of biochar. In Biochar for Environmental Management: Science and Technology (Ed.) J. Lehmann and S. Joseph. Earthscan, London; Sterling, VA,pp. 13-32.

El-Missiry, H. F. E. (2001) Productivity of some salt-affected soils as influenced by chemical amendments and organic materials. Ph.D.Thesis, Fac. of Agric. MashtohorZagazig Univ. (Benha Branch), Egypt.

Evanylo, G., Sherony, C., Spargo, J., Starner, D., Brosius, M. and Haering, K. (2008) Soil and water environmental effects of fertilizer-, manure-, and compost-based fertility practices in an organic vegetable cropping system. Agriculture, Ecosystems \& Environment, 127, 50-58.

Getachew Agegnehu, Adrian M. Bass, Paul N. Nelson, Michael I. Bird (2015) Benefits of biochar, compost and biochar-compost for soil quality, maize yield and greenhouse gas emissions in a tropical agricultural soil. Science of the Total Environment. journal homepage: www.elsevier.com/locate/scitotenv

Glaser, B., Lehmann, J. and Zech, W. (2002) Ameliorating physical and chemical properties of highly weathered soils in the tropics with charcoal - a review. Biology and Fertility of Soils, 35, 219-230.

Gomez, K.A. and Gomez, A.A. (1984) Statistical Procedures for Agricultural Research, 2nd edition. John Wiley and Sons, New York, 680.

Hussain, N., Hassan, G., Arshadullah, M. and Mujeeb, F. (2001) Evaluation of amendments for the improvement of physical properties of sodic soil. Intl. J. Agric. Bio., 3, 319-322.

Ingram D.T. and Millner, P.D (2007) Factors Affecting Compost Tea as a Potential Source of Escherichia coli and Salmonella on Fresh Produce. J. Food Prot., vol. 70, No. 4, Food Safety Implications of a Popular Farming Practice: Compost Tea.

Karer, J., Wimmer, B., Zehetner, F., Kloss, T. and Soja,G. (2013) Biochar application to temperate soils: effects on nutrient uptake and crop yield under field conditions. Agric. and Food Sci. 22, 390-403.

Laird, D., Fleming, P., Davis, D.D., Horton, R.,Wang, B. and Karlen, D. (2010) Impact of biochar amendments on quality of a typical Midwestern agricultural soil. Geoderma. 158, 443-449.

Major, J, Steiner, C., Downie, A. and Lehmann, J. (2009) 'Biochar effects on nutrient leaching', in J Lehmann \& J Stephen (Eds), Biochar for environmental management: Sci. and technology, Earthscan, London, pp. 271-87. 
Michael, A.M., (1978) Irrigation Theory and Practice. Vikas Publishing House, New Delhi.

Ouedraogo, E., Mando, A . and Zombre, N. P. (2001) Use of compost to improve soil properties and crop productivity under low input agricultural system in West Africa. Agriculture Ecosystems \& Environment, 84, 259-266.

Ouyang, L., Wang, F.,Tang, J.,Yu, L. and Zhang, R. (2013) Effects of biochar amendment on soil aggregates and hydraulic properties. Journal of Soil Science and Plant Nutrition. 13, 991-1002.

Page, A.L.R., Miller, H. and Keeney, D.R. (1982) Methods of Soil Analysis. Part 2: Chemical and Microbiological Properties. 2nd Edition, Agronomy Monograph, no. 9, ASA, CSSA, and SSSA, Madison.

Poraas, M., Salwa, M.E., Eisa, A.I., Shaban, Kh.A. and Sallam, A.M. (2008) Effect of applied organic and bio-fertilizers on the productivity and grains quality of maize grown in saline soil. Egypt J. Soil Sci., 48(4), 485 - 500 .

Rajkovich, S., Enders, A., Hanley, K., Hyland, C., Zimmerman, A.R. and Lehmann, J. (2012) Corn growth and nitrogen nutrition after additions of biochars with varying properties to a temperate soil. Biology and Fertility of Soils, 48, 271-284.

Sarwar, G., Schmeisky, H., Hussain, N., Muhammad, S., Ibrahim, M. and Ehsan Safdar (2008) Improvement of soil physical and chemical properties with compost application in .rice-wheat cropping system. Pak. J. Bot., 40(1), 275-282.

Scheuerell, S.J. and Mahaffee, W.F. (2002) Compost Tea Principals and Prospects for Plant Disease Control. Compost Science and Utilization 10, 4:313- 338. (Review)

Schulz, H., Dunst, G. and Glaser, B. (2013) Positive effects of composted biochar on plant growth and soil fertility. Agron Sustain Dev. 33, 817-827.

Suriyan, Cha-um and Chalermpol, Kirdmanee (2011) Remediation of salt-affected soil by the addition of organic matter - an investigation into improving glutinous rice productivity Sci. Agric. (Piracicaba, Braz.), 68 (4), 406-410.

Thomas, S.C., Frye, S., Gale, N., Garmon, M., Launchbury, R., Machado, N., Melamed, S., Murray, J., Petroff, A \&Winsborough C. (2013) Biochar mitigates negative effects of salt additions on two herbaceous plant species. J. Environ Manage. 129, 62-68.

Van Beers, W.F.J. (1958) The Auger-Hole method, Bulletin 1, Int. Inst. for land recl. and impor, Wageningen, The Netherland.

Wong, V.N.L., Dalal, R.C. and Greene, R.S.B. (2009) Carbon dynamics of sodic and saline soil following gypsum and organic material additions: A Laboratory Incubation. Applied Soil Ecology, 41, 29-40.

(Received 26/7/2016; accepted 13/11/2016) 


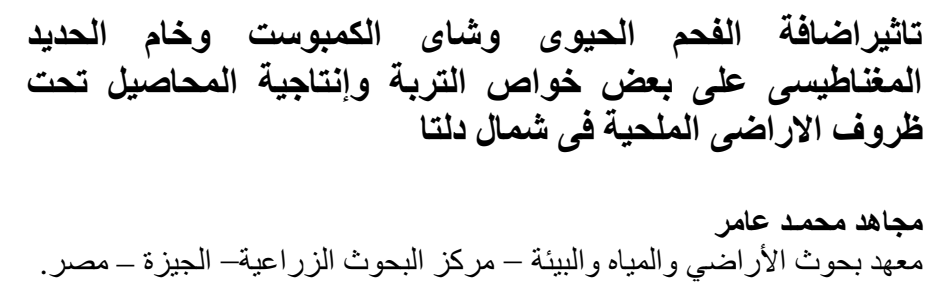

أجريت تجربتان حقليتان فى المزرعة البحثية بمحطة البحوث الزراعية بسخا

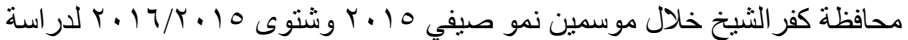

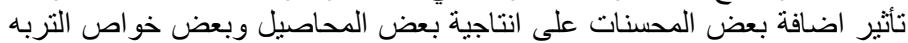

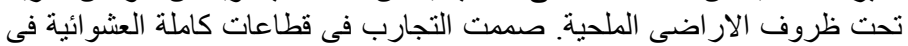

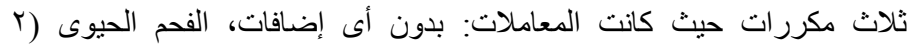

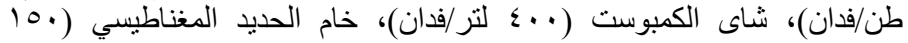

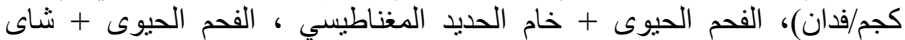

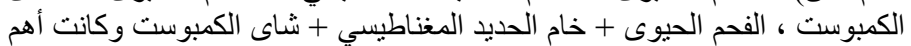
النتائج المتحصل عليها تتلخص ، الفحى في النقاط التالية:

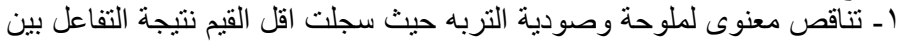

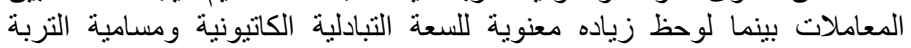

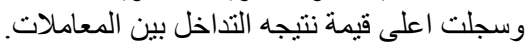

r- تتاقص معنوى فى الكثافة الظاهرية حيث سجلت التهات اقل القيم نتيجة التفاعل بين

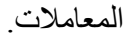
بـ زيادة معنوية فى كل من معدل الرشح و التوصيل الهيدروليكى حيث سجلت اعلى لئى

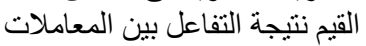

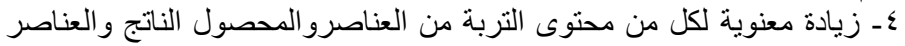

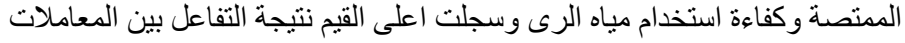

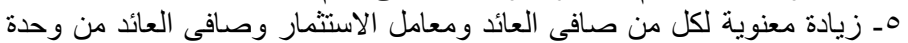

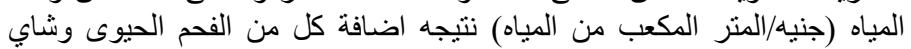

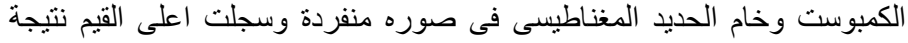

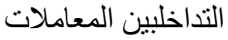
و على ذللك يمكن التوصية بأنه يمكن تحسين بعض الخدون الخواص الكيميائية والطبيعية

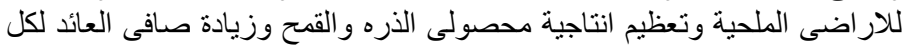

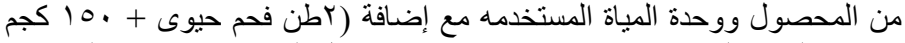

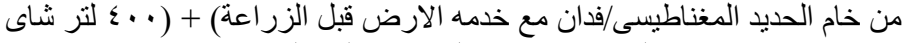

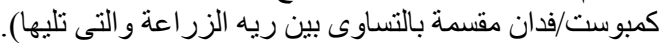

